\title{
Bee bread as a functional product: Chemical composition and bioactive properties
}

\author{
Meryem Bakour $^{\mathrm{a}}$, Ângela Fernandes ${ }^{\mathrm{b}}$, Lillian Barros ${ }^{\mathrm{b}, * *}$, Marina Sokovic $^{\mathrm{c}}$, Isabel C.F.R. Ferreira ${ }^{\mathrm{b}, *}$, \\ Badiaa lyoussi ${ }^{\mathrm{a}}$ \\ ${ }^{a}$ Laboratory of Physiology Pharmacology and Environmental Health, Department of Biology, Faculty of Sciences Dhar Mehraz, University Sidi Mohamed Ben Abdellah, \\ 30000, Fez, Morocco \\ ${ }^{\mathrm{b}}$ Centro de Investigação de Montanha (CIMO), Instituto Politécnico de Bragança, Campus de Santa Apolónia, 5300-253, Bragança, Portugal \\ ${ }^{\mathrm{c}}$ University of Belgrade, Department of Plant Physiology, Institute for Biological Research "Siniša Stanković", Bulevar Despota Stefana 142, 11000, Belgrade, Serbia
}

\section{A R T I C L E I N F O}

\section{Keywords:}

Bee bread

Nutritional value

Chemical composition

Phenolic compounds

Antioxidant and antimicrobial activities

\begin{abstract}
A B S T R A C T
Bee bread is a mixture of pollen pellets, honey and lactic acid bacteria, and the basis of food in the hive. In the present study, a Moroccan bee bread has been analyzed concerning the palynological analysis, nutritional value and chemical composition (free sugars, organic acids, mineral composition, fatty acid, tocopherols and polyphenols); in vitro antioxidant activity and antimicrobial activity screened against pathogenic bacteria and fungi were also evaluated. The studied bee bread was a good source of protein (19.96 $\pm 0.08 \mathrm{~g} / 100 \mathrm{~g})$, total free sugars $(18 \pm 1 \mathrm{~g} / 100 \mathrm{~g})$, macroelements and microelements content, revealed high levels of polyunsaturated fatty acids $(64.7 \pm 0.4 \%)$, tocopherols $(10.9 \pm 0.9 \mathrm{mg} / 100 \mathrm{~g})$ and natural antioxidants, such as flavonol glycoside derivatives, being isorhamnetin- $O$-hexosyl- $O$-rutinoside the major phenolic compound present. The bee bread showed antioxidant activity and effectiveness against all the bacteria and fungi tested. This work contributes to the chemical and bioactive knowledge of this unexplored natural product.
\end{abstract}

\section{Introduction}

Bee products such as honey, propolis, pollen, royal jelly and bee venom are among the most popular natural products used in folk medicine due to their powerful healing properties and their content in bioactive molecules (Brown, Roberts, Cooper, \& Jenkins, 2016). This is why many publications are currently devoted to the study of the therapeutic effects and chemical composition of these products (Fratini, Cilia, Mancini, \& Felicioli, 2016; Zhou et al., 2015).

Bee bread is also a product of the hive being unexplored by many beekeepers, which do not collect this product, due to partial destruction of the hive during the harvest (Urcan et al., 2017). It is the result of lactic fermentation of pollen collected by bees from flowers of melliferous plants and mixed by their digestive enzymes, then they are carried into the hive and kept with a thin layer of honey and bee wax. Bee bread is the main food in the hive especially for larvae and young bees that produce royal jelly (Kieliszek et al., 2018).

In the hive, bee nutrition comes from two main plant origin sources, such as nectar and pollen. The nectar is brought to the hive and turned into honey and provides bees with a source of carbohydrates, and pollen from flowers are transformed into bee bread which provides bees with carbohydrates and other necessary nutrients (protein, fat, minerals, and vitamins). This product is also a good source of antioxidant compounds such as phenolic compounds, $\alpha$-tocopherol, and coenzyme $\mathrm{Q}_{10}$ (Urcan et al., 2017; Zuluaga, Serratob, \& Quicazana, 2015).

The studies on the chemical composition of bee bread showed that it is usually composed of water, proteins, free amino acids, carbohydrates, fatty acids and other bioactive molecules; this composition varies from region to region, depending on the melliferous plants of that region, and also depending on the climatic conditions and seasonal variation (Baltrušaitytè, Venskutonis, \& Čeksterytè, 2007; Urcan et al., 2017).

Bee bread nutritional value is higher than bee pollen and it is more digestible due to the presence of a higher content of free amino acids and easily assimilated sugars (Kieliszek et al., 2018). In comparison with other bee products, studies on bee bread are scarce and limited especially concerning their chemical composition (Bakour et al., 2017; Kaplan, Karaoglu, Eroglu, \& Silici, 2016; Sobral et al., 2017; Tavdidishvili, Khutsidze, Pkhakadze, Vanidze, \& Kalandia, 2014; Čeksteryte et al., 2016; Čeksteryte \& Jansen, 2012) and there are few reports regarding preclinical studies (Bakour et al., 2017; Sobral et al.,

\footnotetext{
* Corresponding author.

** Corresponding author.

E-mail addresses: lillian@ipb.pt (L. Barros), iferreira@ipb.pt (I.C.F.R. Ferreira).
} 
2017).

With this study, it is expected to expand the existing information on the nutritional and chemical characterization of Moroccan bee bread, as well as to explore it's in vitro antioxidant and antimicrobial activities.

\section{Material and methods}

\subsection{Collection of bee bread sample}

Bee bread sample was obtained from professional beekeeper, Imouzer Marmoucha, Morocco. Afterward's, they were lyophilized (FreeZone 4.5, Labconco, MO, USA) and stored at $-20 \mathrm{C}^{\circ}$ until further analysis.

Data was expressed in mean values of three replicates and expressed as mean $\pm \mathrm{SD}$.

\section{2. $p H$ and free acidity}

The $\mathrm{pH}$ and free acidity was carried out by adding $2 \mathrm{~g}$ of bee bread with $5 \mathrm{~mL}$ of milli-Q water. The $\mathrm{pH}$ was determined using a $\mathrm{pH}$ meter and the titration was carried out with $\mathrm{NaOH}(0.05 \mathrm{M})$ up to a $\mathrm{pH}$ of 8.5 (Costa, Morgano, Ferreira, \& Milani, 2017).

\subsection{Palynological analysis of the bee bread}

The palynological analysis of the bee bread was determined according to a method described by Kostić et al. (2015). The bee bread $(500 \mathrm{mg}$ ) was macerated in $15 \mathrm{~mL}$ of $96 \%$ ethanol for $24 \mathrm{~h}$ and then passed into an ultrasonic bath for $5 \mathrm{~min}$, centrifuged for $3 \mathrm{~min}$, and the supernatant was removed. The process was repeated until a homogeneous suspension was obtained, and the resulting pellet was suspended in $20 \mathrm{~mL}$ of distilled water. A slide was prepared by adding a drop in the suspension obtained a drop of a mixture of gelatin, glycerin, phenol, basic fuchsine and distilled water. At least 500 grains of pollen were counted and identified based on reference slides and other pollen morphology guide lines (Schüler \& Hemp, 2016).

\subsection{Nutritional and chemical composition of bee bread}

Nutritional value. For macronutrients analysis, total protein (AOAC 978.04), total fat (AOAC 920.85), and ash (AOAC 923.03) were determined using standard analytical methods described by American Organization of Analytical Chemists International (AOAC International) procedures (AOAC, 2016). Total carbohydrates were calculated by difference and energetic contribution was calculated according to the following equation:

Energy $(\mathrm{kcal})=4 \times\left(\mathrm{g}_{\text {protein }}+\mathrm{g}_{\text {carbohydrates }}\right)+9 \times\left(\mathrm{g}_{\text {fat }}\right)$ (Barros et al., 2013).

Mineral content. The mineral composition of bee bread was analyzed using Inductively coupled plasma-atomic emission spectroscopy (ICPAES). A amount of $10 \mathrm{~g}$ of bee bread was placed in quartz capsules and incinerated at $650{ }^{\circ} \mathrm{C}$ for $4 \mathrm{~h}$, the white ash obtained was dissolved in $50 \mathrm{~mL}$ of $0.5 \mathrm{~N}$ nitric acid; the test was performed in duplicate and were determined macroelements ( $\mathrm{Ca}, \mathrm{Fe}, \mathrm{K}, \mathrm{Mg}, \mathrm{Na}, \mathrm{Mn}, \mathrm{Zn}$, and $\mathrm{P}$ ) and microelements and toxic metals contents ( $\mathrm{Cd}, \mathrm{Co}, \mathrm{Cu}, \mathrm{Ni}, \mathrm{Se}$, and $\mathrm{Pb}$ ) (AOAC, 2016).

Free sugars. Free sugars were determined by HPLC coupled to a RI detector (Knauer, Smartline system 1000, Berlin, Germany) using the internal standard (IS, melezitose) methodology as previously described (Barros et al., 2013) and results were expressed in $\mathrm{g}$ per $100 \mathrm{~g}$ of bee bread (BB).

Organic acids. Organic acids were determined following a procedure previously described by the authors (Barros et al., 2013) and the analysis was performed by ultra-fast liquid chromatography coupled to photodiode array detection (UFLC-PDA; Shimadzu Coperation, Kyoto, Japan), using $215 \mathrm{~nm}$ as preferred wavelength(oxalic acid were purchased from Sigma-Aldrich, St. Louis, MO, USA). Results were expressed in $\mathrm{g}$ per $100 \mathrm{~g}$ of bee bread (BB).

Fatty acids. Fatty acids were determined with a gas chromatographer coupled to a flame ionization detector (GC-FID, DANI model GC 1000 instrument, Contone, Switzerlandas previously described by the authors (Barros et al., 2013) and the results were expressed as relative percentage (\%) of each fatty acid.

Tocopherols. Tocopherols were determined following a procedure previously described by the authors (Barros et al., 2013) using a HPLC system (Knauer, Smartline system 1000, Berlin, Germany) coupled to a fluorescence detector (FP-2020; Jasco, Easton, USA) programmed for excitation at $290 \mathrm{~nm}$ and emission at $330 \mathrm{~nm}$ and using the IS (tocol) method for quantification $(\alpha-, \beta-, \gamma-$, and $\delta$-isoforms were purchased from Sigma.). The results were expressed in $\mathrm{mg}$ per $100 \mathrm{~g}$ of bee bread (BB).

\subsection{Phenolic compounds profile of bee bread}

Preparation of hydromethanolic extracts. For extraction, $1 \mathrm{~g}$ of bee bread was stirred with $30 \mathrm{~mL}$ of a mixture of methanol/water (80:20 v/ $v$, at $25^{\circ} \mathrm{C}$ at $150 \mathrm{rpm}$ ) for $60 \mathrm{~min}$, and afterwards filtered (Whatman paper No. 4). The residue was re-extracted with an additional $30 \mathrm{~mL}$ portion of the hydromethanolic mixture and the combined supernatants were evaporated under reduced pressure (rotary evaporator Büchi R210, Flawil, Switzerland) to remove the methanol. The aqueous phase was lyophilized (FeeeZone 4.5, Labconco, Kansas City, MO, USA).

Phenolic compounds profile analysis. The hydromethanolic extract was re-dissolved in methanol/water $(80: 20 \mathrm{v} / \mathrm{v})$ to a final concentration of $20 \mathrm{mg} / \mathrm{mL}$ for the phenolic compounds identification and quantification, which was performed in a LC-DAD-ESI/MSn analysis (Dionex Ultimate 3000 UHPLC instrument, Thermo Scientific, San Jose, CA, USA) equipped with a diode-array detector and coupled to a mass detector, following a procedure previously reported (Bessada, Barreira, Barros, Ferreira, \& Oliveira, 2016). The phenolic compound standards were obtained from Extrasynthese (Genay, France). The chromatograms were recorded at several wavelengths, characteristic of the different polyphenol classes $(280,330$ and $370 \mathrm{~nm}$ ) and the mass spectrometer detection was performed in negative mode. For quantitative analysis, a calibration curve was constructed based on the UV-Vis signal of quercetin-3-O-glucoside (Q3G, $y=34843 \mathrm{x}-160173$, $R^{2}=0.999$ ) and all compounds were quantified as Q3G equivalents. The results were expressed in $\mathrm{mg}$ per $\mathrm{g}$ of bee bread extract.

\subsection{Bioactive properties of bee bread}

\subsubsection{Antioxidant activity}

Total antioxidant capacity. The antioxidant activity of the hydromethanolic extract of bee bread, mentioned above was evaluated by the phosphor-molybdenum method according to the procedure of Zengin, Arkan, Aktumsek, Guler, and Cakmak (2013). The antioxidant capacity of the bee bread extract was expressed as ascorbic acid equivalents (mg $\mathrm{AA} / \mathrm{g}$ of bee bread extract).

Scavenging activity of the free radical DPPH. Scavenging activity of the free radical DPPH was measured as described previously (Miguel, Doughmi, Aazza, Antunes, \& Lyoussi, 2014) and the absorbance was measured at $517 \mathrm{~nm}$. The tests were carried out in three repetitions, and butylated hydroxytoluene (BHT) was used as a positive control, the scavenging activity was estimated based on the percentage of DPPH radical scavenged using the following equation:

$\mathrm{EC}_{50} \%=\left[\left(\mathrm{A}_{0}-\mathrm{A}_{1} / \mathrm{A}_{0}\right) \times 100\right]$

$\mathrm{A}_{0}$ is the absorbance of a negative control (blank sample containing the same amount of solvent and DPPH solution) and $A_{1}$ is the absorbance of the sample.

Scavenging activity of the free radical ABTS. ABTS radical scavenging 
activity was evaluated accordingly to Zengin et al. (2013). The ABTS free radical was generated by reaction between $7 \mathrm{mM}$ ABTS aqueous solution with $\mathrm{K}_{2} \mathrm{~S}_{2} \mathrm{O}_{8}(2.45 \mathrm{mM})$ in the dark for $16 \mathrm{~h}$ and adjusting the absorbance at $734 \mathrm{~nm}$ to 0.7 at room temperature. A volume of $75 \mu \mathrm{L}$ of bee bread extract and BHT (used as positive control) were added to $825 \mu \mathrm{L}$ of ABTS and the absorbance at $734 \mathrm{~nm}$ was read after 6 min with a Perkin Elmer Lambda 40 UV/VIS spectrophotometer. All tests were carried out in triplicate. The capability to scavenge the ABTS radical was calculated using the following equation:

$\mathrm{EC}_{50} \%=\left[\left(\mathrm{A}_{0}-\mathrm{A}_{1} / \mathrm{A}_{0}\right) \times 100\right]$

$\mathrm{A}_{0}$ is the absorbance of a negative control (blank sample containing the same amount of solvent and ABTS solution) and $\mathrm{A}_{1}$ is the absorbance of the sample.

Reducing power (RP). The reducing power was determined accordingly to the authors (Padmanabhan \& Jangle, 2012) with some modifications. The hydromethanolic extract of bee bread $(50 \mu \mathrm{L})$ were mixed with $200 \mu \mathrm{L}$ of $0.2 \mathrm{M}$ sodium phosphate buffer $(\mathrm{pH} \mathrm{6.6)}$ and $200 \mu \mathrm{L}$ of $1 \%$ potassium ferricyanide. The mixture was incubated at $50{ }^{\circ} \mathrm{C}$ for $20 \mathrm{~min}$. After $200 \mu \mathrm{L}$ of $10 \%$ trichloroacetic acid was added and was mixed with $600 \mu \mathrm{L}$ of distilled water plus $120 \mu \mathrm{L}$ of $0.1 \%$ ferric chloride. The absorbance of the mixture was measured at $700 \mathrm{~nm}$ with a Perkin Elmer Lambda 40 UV/VIS spectrophotometer. Ascorbic acid was used as a positive control.

The results were represented in $\mathrm{EC}_{50}$ values, corresponding to the concentration providing $50 \%$ of antioxidant activity or 0.5 of absorbance in the reducing power assay measured at $700 \mathrm{~nm}$.

\subsubsection{Antimicrobial activity of bee bread}

The hydromethanolic extract was prepared at a final concentration of $20 \mathrm{mg} / \mathrm{mL}$ in water, and then it was further diluted to different concentrations to be submitted to the antimicrobial evaluation. The following Gram-positive bacteria: Bacillus cereus (food isolate), Staphylococcus aureus (ATCC 6538) and Listeria monocytogenes (NCTC 7973); Gram-negative bacteria: Escherichia coli (ATCC 35210), Enterobacter cloacae (human isolate), Salmonella typhimurium (ATCC 13311); and fungi: Aspergillus fumigatus (ATCC 1022), Aspergillus ochraceus (ATCC 12066), Aspergillus niger (ATCC 6275), Penicillium funiculosum (ATCC 36839), Penicillium ochrochloron (ATCC 9112), and Penicillium verrucosum var. cyclopium (food isolate) were used in this study. The antimicrobial assay was carried out by the microdilution method as previously described by (Soković, Glamočlija, Marin, Brkić, \& Griensven, 2010). The results were expressed as the concentrations that completely inhibited bacterial growth (MIC, minimal inhibition concentration), and were determined by a colorimetric microbial viability assay, and MBC and MFC (minimal bactericidal concentration and minimal fungicidal concentration) were also calculated. Streptomycin, ampicillin, ketoconazole and bifonazole (Sigma-Aldrich, St. Louis, MO, USA) were used as positive controls and 5\% DMSO was used as a negative control.

\subsubsection{Hepatotoxicity assays}

The hydromethanolic extracts were re-dissolved at a concentration of $8 \mathrm{mg} / \mathrm{mL}$ in water and DMSO $(10 \%)$, and then they were further diluted to different concentrations (from 400 to $6.25 \mu \mathrm{g} / \mathrm{mL}$ ). The hepatotoxicity was evaluated against non-tumor porcine liver cell line (PLP2), obtained using a cell culture from freshly harvested porcine liver acquired from certified slaughter houses. To monitor the cell culture growth a phase-contrast microscope was used, and then the cells were sub-cultured and plated in 96 well plates (density of $1.0 \times 10^{4}$ cells/well), using a DMEM medium, with $10 \%$ of FBS, $100 \mathrm{U} /$ $\mathrm{mL}$ of penicillin and $100 \mu \mathrm{g} / \mathrm{mL}$ of streptomycin. The results were obtained using the sulphorhodamine assay, as previously performed by (Sobral et al., 2016). Results were expressed as $\mathrm{GI}_{50}(\mu \mathrm{g} / \mathrm{mL})$ and ellipticine was used as a positive control.
Table 1

Proximate composition (g/100 g BB), energetic value (kcal/100 g BB), macroelements (mg/100 g BB), microelements and toxic metals ( $\mu \mathrm{g} / 100 \mathrm{~g} \mathrm{BB})$, free sugars ( $\mathrm{g} / 100 \mathrm{~g} \mathrm{BB})$, and organic acids $(\mathrm{g} / 100 \mathrm{~g} \mathrm{BB})$ in bee bread (mean $\pm \mathrm{SD}$ ).

\begin{tabular}{llll}
\hline \multicolumn{3}{l}{ Proximate composition } & Free sugars \\
\hline Fat & $1.90 \pm 0.06$ & Fructose & $11.8 \pm 0.6$ \\
Proteins & $19.96 \pm 0.08$ & Glucose & $5.7 \pm 0.4$ \\
Ash & $3.32 \pm 0.08$ & Trehalose & $0.92 \pm 0.01$ \\
Carbohydrates & $74.82 \pm 0.04$ & Total sugars & $18 \pm 1$ \\
Energy & $396.2 \pm 0.4$ & & \\
\hline
\end{tabular}

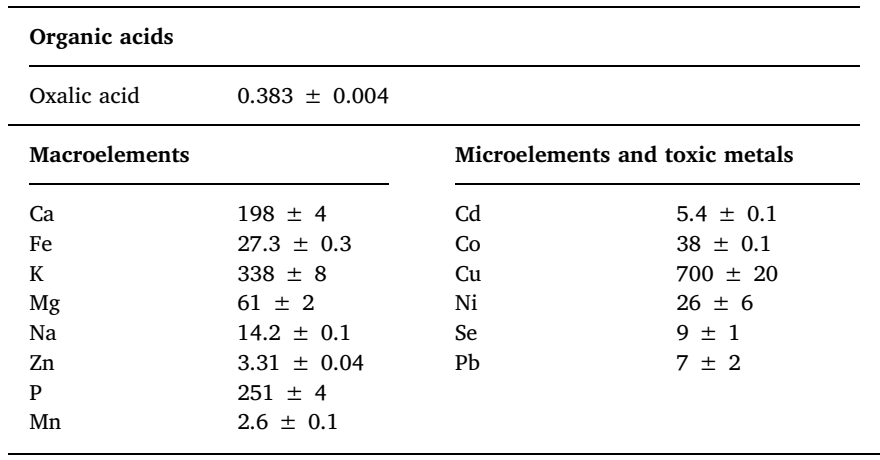

\section{Results and discussion}

\subsection{Palynological analysis of the bee bread}

Six plant families were identified in the analyzed bee bread: Apiaceae (Bupleurum spinosum; Anethum graveolens) predominant with a percentage of $35 \%$, Asteraceae (Calendula officinalis; Anacyclus) with a percentage of $24 \%$, Fagaceae (Quercus ilex) with a percentage of $16 \%$, Myrtaceae (Eucalyptus) 9\%, Punicaceae (Punica granatum) 6\%, Mimosaceae (Acacia) 5\%; and 5\% other types of pollen grains. According to Saavedra-Carhuatocto, Aguinaga-Castro, Rojas-Idrogo, and Delgado-Paredes (2014) the bee bread sample is classified as multifloral, because it contains 3 types of pollen with secondary percentages (16-45\%).

\subsection{Nutritional value and chemical composition of bee bread}

The results of the nutritional composition are showed in Table 1 and demonstrated that carbohydrates $(74.82 \pm 0.04 \mathrm{~g} / 100 \mathrm{~g}$ bee bread $\mathrm{BB})$ followed by proteins $(19.96 \pm 0.08 \mathrm{~g} / 100 \mathrm{~g} \mathrm{BB})$ were the main macronutrients in $\mathrm{BB}$. The minor contents were found for ash $(3.32 \pm 0.08 \mathrm{~g} / 100 \mathrm{~g} \mathrm{BB})$ and fat $(1.90 \pm 0.086 \mathrm{~g} / 100 \mathrm{~g} \mathrm{BB})$, revealing an overall energetic contribution of $396.2 \pm 0.4 \mathrm{kcal} / 100 \mathrm{~g}$ $\mathrm{BB})$. The $\mathrm{pH}$ and the free acidity was found at $4.37 \pm 0.02$ and $400 \pm 15 \mathrm{mEq} / \mathrm{kg} \mathrm{BB}$, respectively.

Kaplan et al. (2016) described that the lipid content in bee bread samples of clover, cotton, chestnut, citrus, and sunflower ranged between $5.93 \mathrm{~g} / 100 \mathrm{~g}$ BB and $11.55 \mathrm{~g} / 100 \mathrm{~g}$ BB. Another study with fifteen bee bread samples revealed that the lipid content ranged from $1.65 \%$ to $5.50 \%$ (Zuluaga et al., 2015); otherwise, Andjelkovic, Jevtic, Markovic, Mladenovic, and Pseva (2012) in Serbian bee bread samples, reported that the lipid content ranged between $4.51 \%$ and $4.92 \%$. The protein content in bee bread samples from Colombian and Serbia ranged from $27.6 \%$ to $29.9 \%$, respectively (Andjelkovic et al., 2012; Zuluaga et al., 2015). The differences found between the samples could be due to the floral origin of the bee bread (Urcan et al., 2017).

Regarding mineral composition of bee bread (Table 1), the predominant minerals in the sample were potassium $(338 \pm 8 \mathrm{mg} / 100 \mathrm{~g}$ of BB), followed by phosphorus ( $251 \pm 4 \mathrm{mg} / 100 \mathrm{~g}$ of $\mathrm{BB}$ ), calcium $(198 \pm 4 \mathrm{mg} / 100 \mathrm{~g}$ of BB$)$, magnesium $(61 \pm 2 \mathrm{mg} / 100 \mathrm{~g}$ of $\mathrm{BB})$, iron $(27.3 \pm 0.3 \mathrm{mg} / 100 \mathrm{~g}$ of $\mathrm{BB})$, sodium $(14.2 \pm 0.1 \mathrm{mg} / 100 \mathrm{~g}$ of $\mathrm{BB})$, zinc $(3.31 \pm 0.04 \mathrm{mg} / 100 \mathrm{~g}$ of $\mathrm{BB})$ and manganese $(2.6 \pm 0.1 \mathrm{mg} /$ 
$100 \mathrm{~g}$ of $\mathrm{BB})$. Concerning the microelement and toxic metals analysis, the highest content was represented by copper $(700 \pm 20 \mu \mathrm{g} / 100 \mathrm{~g}$ of $\mathrm{BB})$, followed by cobalt $(38 \pm 1 \mu \mathrm{g} / 100 \mathrm{~g}$ of BB), nickel $(26 \pm 6 \mu \mathrm{g} /$ $100 \mathrm{~g}$ of $\mathrm{BB})$, selenium $(9 \pm 1 \mu \mathrm{g} / 100 \mathrm{~g}$ of $\mathrm{BB})$, and with lowest concentrations of lead $(7 \pm 2 \mu \mathrm{g} / 100 \mathrm{~g}$ of $\mathrm{BB})$ and cadmium $(5.4 \pm 0.1$ $\mu \mathrm{g} / 100 \mathrm{~g}$ of $\mathrm{BB})$. The bee bread sample studied herein is safe for human consumption, because it meets the quality requirement imposed, in which the lead content should not exceed $50 \mu \mathrm{g} / 100 \mathrm{~g}$ and the cadmium content should not exceed $10 \mu \mathrm{g} / 100 \mathrm{~g}$ (Campos et al., 2008).

In a study of Andjelkovic et al. (2012) mineral content of bee bread of dandelion and deadnettle reveal that the predominant mineral was potassium, followed by phosphorus calcium and magnesium, which is in agreement with those reported in this study. According to Loper, Standifer, Thompson, and Gilliam (1980), also potassium present the highest mineral in almond bee bread, followed by calcium, magnesium and zinc. The same results are registered by Stanciu, Marghitas, and Dezmirean (2009) in bee bread from the Transylvania region, Romania. The main source of these minerals for the honey bees is the pollen of flowers and, according to Andjelkovic et al. (2012), the nectar and the water can also be an important source of these inorganic elements. However, other factors such as geographical conditions and soil also affect the mineral content of bee bread.

The analysis of free sugars (Table 1 ) revealed that fructose is the representative one $(11.8 \pm 0.6 \mathrm{~g} / 100 \mathrm{~g} \mathrm{BB})$, followed by glucose $(5.7 \pm 0.4 \mathrm{~g} / 100 \mathrm{~g} \mathrm{BB})$ and trehalose $(0.92 \pm 0.01 \mathrm{~g} / 100 \mathrm{~g} \mathrm{BB}) . \mathrm{Su}-$ gars are the main source of energy expenditure for bees, worker bees require about $4 \mathrm{mg}$ of usable sugars per day to survive, and fructose is the most neglected sugar, followed by glucose and maltose (Brodschneider \& Crailsheim, 2010). Sucrose appears in a low percentage due to its decomposition during lactic fermentation, in which bacteria use these sugars as a source of oxygen to produce lactic acid. The bee bread also contains the disaccharides trehalose, isomaltose and turanose, but in a very small percentage (Urcan et al., 2017). Nevertheless, these sugars were not present in the herein studied BB.

Concerning organic acids, oxalic acid was the only compound quantified in bee bread $(0.383 \pm 0.004 \mathrm{~g} / 100 \mathrm{~g} \mathrm{BB})$. To our knowledge these compounds have not been explored in $\mathrm{BB}$, being this the first report.

A total of twenty-five fatty acids including fourteen saturated and eleven unsaturated were identified in bee bread samples (Table 2). The results showed high levels of polyunsaturated fatty acids (PUFAs) $(64.7 \pm 0.4 \%)$, owing to the presence of high levels of $\alpha$-linoleic (C18:3n3, $25 \pm 1 \%$ ), arachidonic (C20:4n6, $23.2 \pm 0.5 \%)$, and linoleic $(\mathrm{C} 18: 2 \mathrm{n} 6,14.2 \pm 0.1 \%)$. It was also possible to find the presence of three omega-3 fatty acid ( $\alpha$-linoleic, eicosatrienoic, eicosapentaemoic acids), as also three omega-6 (linoleic, eicosatrienoic, and arachidonic). Concerning monounsaturated fatty acids, the bee bread sample contain $7.2 \pm 0.3 \%$, being oleic acid (C18:0, $5.7 \pm 0.3 \%)$ the most abundant fatty acid. Palmitic acid (C16:0, $10.6 \pm 0.4 \%)$ was the most abundant saturated fatty acids, which were the second highest group present (SFA, $27.8 \pm 0.8 \%$ ).

Current literature shows that bee bread is a good source of fatty acids, especially polyunsaturated, which are very important for human health. Kaplan et al. (2016) identified 37 fatty acids including twenty saturated and seventeen unsaturated in bee bread samples obtained from different botanical origins. In another study performed by Čeksteryte et al. (2016), 39 fatty acids were identified in clover bee bread. Čeksteryte and Jansen (2012) reported that rape and willow bread collected in the spring contained 22 fatty acids, including medium-chain (C10-C18), and long-chain (C20-C24) saturated fatty acids. Human and Nicolson (2006) reported that the bee bread of Aloe greatheadii var. davyana from South African origin contained 18 fatty acids, including long-chain fatty acids, saturated fatty acids and monounsaturated fatty acids.

Regarding tocopherols composition (Table 2), in the analyzed sample $\alpha$-tocopherol $(10.5 \pm 0.8 \mathrm{mg} / 100 \mathrm{~g} \mathrm{BB})$ and $\delta$-tocopherol $(0.40 \pm 0.04 \mathrm{mg} / 100 \mathrm{~g} \mathrm{BB})$ were the only isoforms identified. Hryniewicka, Karpinska, Kijewska, Turkowicz, and Karpinska (2016) found by LC-MS/MS analysis that bee bread is a product rich in vitamin E, especially $\alpha$-tocopherol.

\subsection{Phenolic compounds profile of bee bread}

Concerning the phenolic composition of the Moroccan bee bread sample (Table 3 and Fig. 1), the results show the presence of thirteen compounds, mainly flavonols glycoside derivative, especially quercetin, kaempferol, isorhamnetin, and methylherbacetrin derivatives. The identification of the phenolic compounds present were performed taking into account a previous study performed by Sobral et al. (2017) using Portuguese bee bread samples, and the flavonol glycoside profile was very similar to the samples analyzed in that work. Of all the detected compounds isorhamnetin- $O$-hexosyl-O-rutinoside is the main phenolic compound present in this BB sample.

Another work studying Georgian bee bread revealed the presence of 12-15 flavonoids determined by HPLC (Tavdidishvili et al., 2014). Markiewicz-Zukowska et al. (2013) analyzed bee bread from Poland by GC-MS and found kaempferol and apigenin as the main flavonoids. Isidorov, Isidorova, Sczczepaniak, and Czyżewska (2009) identified by

Table 2

Fatty acids (\%) and tocopherols composition (mg/100 g BB) in bee bread (mean \pm SD).

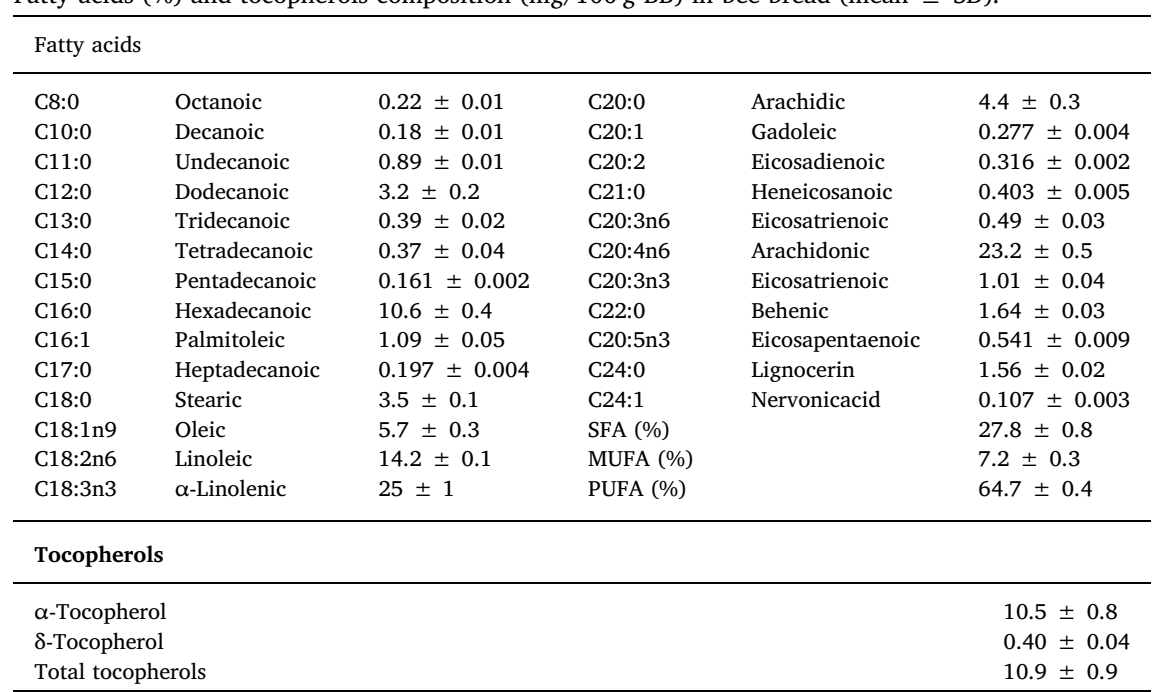


Table 3

Retention time (Rt), wavelengths of maximum absorption in the visible region $\left(\lambda_{\max }\right)$, mass spectral data, identification, and quantification (mean \pm SD) of phenolic compounds in bee bread.

\begin{tabular}{|c|c|c|c|c|c|c|}
\hline Peak & Rt (min) & $\lambda_{\max }(\mathrm{nm})$ & {$[\mathrm{M}-\mathrm{H}]^{-}(m / z)$} & $\operatorname{MS}^{2}(m / z)$ & Tentative identification & Quantification (mg/g extract) \\
\hline 1 & 12.4 & 346 & 755 & 593(100),447(21),285(34) & Kaempferol- $O$-hexosyl- $O$-rutinoside & $0.57 \pm 0.01$ \\
\hline 2 & 13.8 & 350 & 625 & $463(100), 301(36)$ & Quercetin-O-hexosyl-O-hexoside & $0.95 \pm 0.03$ \\
\hline 3 & 14.0 & 350 & 625 & $463(100), 301(48)$ & Quercetin- $O$-hexosyl-O-hexoside & $0.80 \pm 0.01$ \\
\hline 4 & 14.6 & 350 & 639 & $315(100), 300(21)$ & Methylherbacetrin-O-dihexoside & $0.545 \pm 0.004$ \\
\hline 5 & 15.3 & 350 & 785 & $623(100), 477(16), 315(30)$ & Isorhamnetin- $O$-hexosyl-O-rutinoside & $1.48 \pm 0.05$ \\
\hline 6 & 15.9 & 358 & 595 & $301(100)$ & Quercetin-O-pentosyl-hexoside & $0.58 \pm 0.01$ \\
\hline 7 & 16.1 & 358 & 609 & $301(100)$ & Quercetin 3-O-rutinoside & $0.53 \pm 0.01$ \\
\hline 8 & 16.8 & 352 & 623 & $315(100), 300(22)$ & Methylherbacetrin-3-O-rutinoside & $0.51 \pm 0.01$ \\
\hline 9 & 17.9 & 356 & 609 & $315(100)$ & Isorhamnetin-O-pentosyl-hexoside & $0.93 \pm 0.01$ \\
\hline 10 & 18.8 & 356 & 609 & $315(100)$ & Isorhamnetin-O-pentosyl-hexoside & $0.55 \pm 0.01$ \\
\hline 11 & 21.1 & 348 & 593 & $285(100)$ & Kaempferol-3-O-rutinoside & $0.51 \pm 0.01$ \\
\hline 12 & 21.4 & 356 & 623 & $315(100)$ & Isorhamnetin-O-rhamnoside-hexoside & $0.56 \pm 0.01$ \\
\hline \multirow[t]{2}{*}{13} & 22.0 & 356 & 623 & $315(100)$ & Isorhamnetin-3-O-rutinoside & $0.68 \pm 0.01$ \\
\hline & & & & & Total phenolic compounds & $9.2 \pm 0.1$ \\
\hline
\end{tabular}

using a GC-MS analysis, naringenin, kaempferol, apigenin, isorhamnetin, quercetin, and also vitamin $\mathrm{E}$ ( $\alpha$ tocopherol) in bee bread from Latvia, Russia and Poland. A recent study published by Urcan et al. (2018) it was demonstrated that the phenolic profile of BB is identical to the corresponding flora pollen (hand collected) and bee pollen. Despite the biochemical transformation that occurs during the fermentation of the bee bread, the phenolic compounds are unaffected and remain unchanged. In addition, they found that variables such as soil and climate do not appear to influence these compounds in the type of samples studied. Nevertheless, Sobral et al. (2017) studied BB from different origins and detected differences in the phenolic composition of these samples.

The antioxidant activity results (Table 4) revealed a total antioxidant capacity of $143 \pm 22 \mathrm{mg}$ equivalent of $\mathrm{AA} / \mathrm{g}$, the lower $\mathrm{EC}_{50}$ was registered for the reducing power assay $\left(\mathrm{EC}_{50}=0.19 \pm 0.03 \mathrm{mg} /\right.$ $\mathrm{mL}$ ), followed the ABTS assay $\left(\mathrm{EC}_{50}=0.50 \pm 0.04 \mathrm{mg} / \mathrm{mL}\right.$ ), and $\mathrm{DPPH}$ assay $\left(\mathrm{EC}_{50}=0.98 \pm 0.06 \mathrm{mg} / \mathrm{mL}\right.$ ). These results are similar to previous studies which shows that the high content of antioxidants in the bee bread is responsible for these bioactivities. Oltica, Mărghitaş, and Dezmirean (2007) demonstrate that there is a good correlation between the bioactive compounds (flavonols, flavones, and flavanones) and the antioxidant activities performed by the DPPH, TEAC, and FRAP tests. Baltrušaityte et al. (2007) found that bee bread present better antioxidant activity than honey. In another study performed by Akhir, Bakar, and Sanusi (2017) it was shown that the ethanolic extract of bee bread had the highest activity than propolis for the radical scavenging
Table 4

Antioxidant activities of bee bread (mean \pm SD).

\begin{tabular}{lll}
\hline Antioxidant activities & Bee bread & Positive control \\
\hline Total antioxidant capacity $(\mathrm{mg} \mathrm{AA} / \mathrm{g}$ extract) & $143 \pm 22$ & $\mathrm{nq}$ \\
DPPH assay $\left(\mathrm{EC}_{50}, \mathrm{mg} / \mathrm{mL}\right)$ & $0.98 \pm 0.06$ & $0.009 \pm 0.001$ \\
ABTS assay $\left(\mathrm{EC}_{50}, \mathrm{mg} / \mathrm{mL}\right)$ & $0.50 \pm 0.04$ & $0.007 \pm 0.002$ \\
Reducing power $\left(\mathrm{EC}_{50}, \mathrm{mg} / \mathrm{mL}\right)$ & $0.19 \pm 0.03$ & $0.021 \pm 0.001$ \\
\hline
\end{tabular}

nq-not quantified. DPPH and ABTS positive control was BHT, while RP positive control was ascorbic acid.

activity assay, namely DPPH and ABTS assays; for the FRAP assay both hexane extracts of bee bread and propolis, presented higher values in comparison to the ethanolic extracts. These differences can be explained by the different solvents applied in the extraction procedure (70\% ethanol and $n$-hexane).

Concerning the antimicrobial effect of the bee bread sample (Table 5), the results showed that all bacterial strains and fungi were sensitive to the hydromethanolic bee bread extract with MIC values ranging between $0.04 \mathrm{mg} / \mathrm{mL}$ and $0.175 \mathrm{mg} / \mathrm{mL}$, and $\mathrm{MBC}$ ranging from $0.08 \mathrm{mg} / \mathrm{mL}$ to $0.35 \mathrm{mg} / \mathrm{mL}$ for bacterial strains. While for fungi strains MIC values ranged between $0.35 \mathrm{mg} / \mathrm{mL}$ and $1 \mathrm{mg} / \mathrm{mL}$ and MFC ranged between $0.70 \mathrm{mg} / \mathrm{mL}$ and $1.40 \mathrm{mg} / \mathrm{mL}$. The antimicrobial activity of a DMSO extract of Moroccan bee bread samples was previously studied against Staphylococcus aureus, Bacillus cereus, Pseudomonas aeruginosa and Escherichia coli; the results showed that all the samples

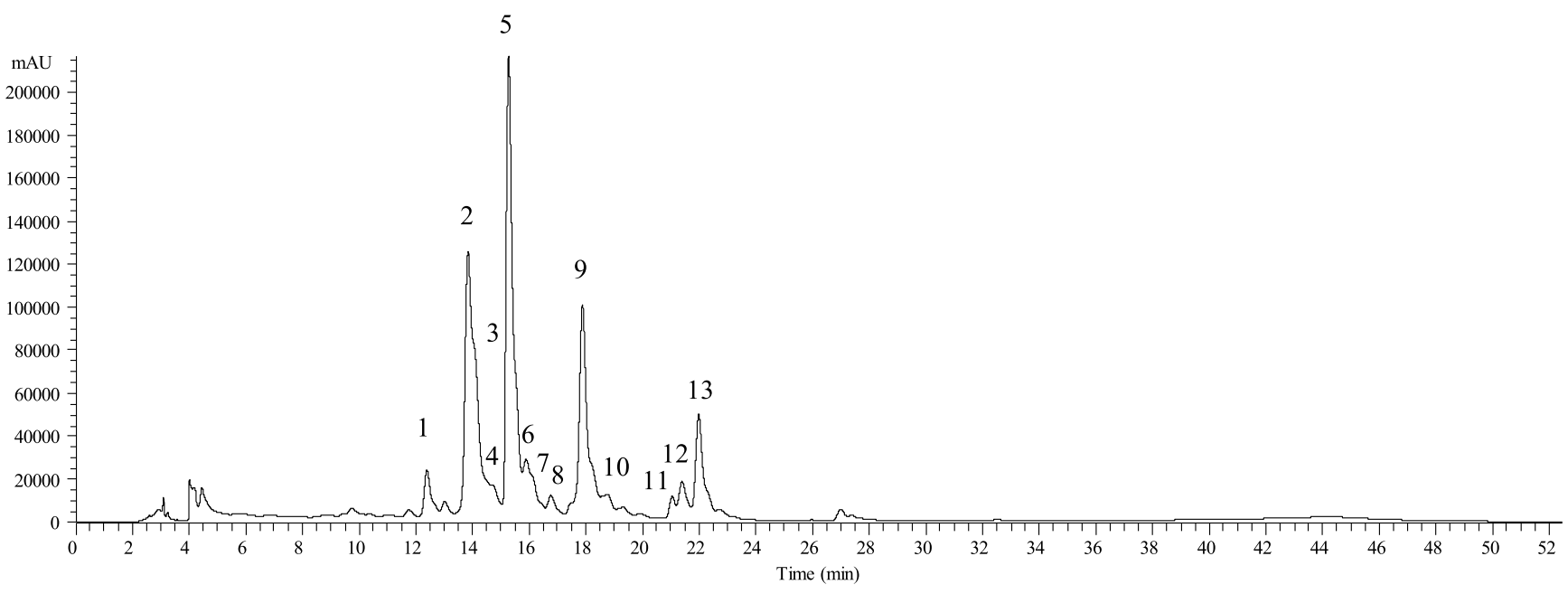

Fig. 1. Phenolic compounds profile found in bee bread recorded at $370 \mathrm{~nm}$. Peak numbering is described in Table 3 . 
Table 5

Antibacterial and antifungal activity of bee bread (MIC, MBC, and MFC mg/mL).

\begin{tabular}{|c|c|c|c|c|c|c|c|}
\hline \multicolumn{2}{|c|}{ Antibacterial activity } & \multirow{2}{*}{$\begin{array}{l}\text { B. cereus } \\
0.04\end{array}$} & \multirow{2}{*}{$\begin{array}{l}\text { S. aureus } \\
0.175\end{array}$} & \multirow{2}{*}{$\begin{array}{l}\text { L. monicytogenes } \\
0.175\end{array}$} & \multirow{2}{*}{$\begin{array}{l}\text { E. coli } \\
0.25\end{array}$} & \multirow{2}{*}{$\begin{array}{l}\text { En. cloacae } \\
0.175\end{array}$} & \multirow{2}{*}{$\begin{array}{l}\text { S. typhimurium } \\
0.175\end{array}$} \\
\hline Bee bread & MIC & & & & & & \\
\hline & MBC & 0.08 & 0.35 & 0.35 & 0.35 & 0.35 & 0.35 \\
\hline \multirow[t]{2}{*}{ Streptomycin } & MIC & 0.10 & 0.04 & 0.20 & 0.20 & 0.20 & 0.20 \\
\hline & MBC & 0.20 & 0.10 & 0.30 & 0.30 & 0.30 & 0.30 \\
\hline \multirow[t]{2}{*}{ Ampicillin } & MIC & 0.25 & 0.25 & 0.40 & 0.40 & 0.25 & 0.75 \\
\hline & MBC & 0.40 & 0.45 & 0.50 & 0.50 & 0.50 & 1.20 \\
\hline \multicolumn{2}{|c|}{ Antifungal activity } & A. fumigatus & A. ochraceus & A. niger & P. funiculosum & P. ochrochloron & P. v. cyclopium \\
\hline \multirow[t]{2}{*}{ Bee bread } & MIC & 0.50 & 0.35 & 1.00 & 0.70 & 1.00 & 1.00 \\
\hline & MBC & 1.00 & 0.70 & 1.40 & 1.00 & 1.40 & 1.40 \\
\hline \multirow[t]{2}{*}{ Ketoconazole } & MIC & 0.25 & 0.20 & 0.20 & 0.20 & 2.50 & 0.20 \\
\hline & MFC & 0.50 & 0.50 & 0.50 & 0.50 & 3.50 & 0.30 \\
\hline \multirow[t]{2}{*}{ Bifonazole } & MIC & 0.15 & 0.10 & 0.15 & 0.20 & 0.20 & 0.10 \\
\hline & MFC & 0.20 & 0.20 & 0.20 & 0.25 & 0.25 & 0.20 \\
\hline
\end{tabular}

revealed antimicrobial activity against the tested bacterial strains, with greater susceptibility for the Gram-positive bacteria than for the Gramnegative bacteria (Abouda, Zerdani, Kalalou, Faid, \& Ahami, 2011). Ivanišová et al. (2015) showed that an ethanolic extract of bee bread samples from five regions of Ukraine also presented antimicrobial activity against four bacterial strains, two Gram-positive (Bacillus thuringiensis and Staphylococcus aureus) and two Gram-negative (E. coli and Salmonella enterica).

The antimicrobial effect of bee bread is probably associated with the presence of antioxidants such as phenolic compounds, especially flavonoids. It is well known that these compounds can affect the growth and metabolism of bacteria, by leading to the disruption of the cell wall integrity, blockage of ion channels and inhibiting the adenosine triphosphate synthesis(ATP) (Kamonwannasit et al., 2013; Vattem, Lin, Labbe, \& Shetty, 2004).

Moreover, the bee bread did not reveal toxicity for normal cells (non-tumor porcine liver primary cells), up to the highest concentration tested $\left(\mathrm{GI}_{50}\right.$ value $>400 \mathrm{~g} / \mathrm{mL}$ ) (data not shown).

\section{Conclusion}

Bee bread is regarded as a valued distinct food. Nutritional, chemical and bioactive characteristics of bee bread from Morocco could play an important role for determining quality control of this product. Particularly, high levels of carbohydrates, proteins, minerals, and fatty acids were found; and presented to be a potentially source of natural antioxidants, such as tocopherols and phenolic compounds. This results depends on the botanical and geographical origin of the bee bread. It is expected that this work would be an important tool for cataloguing and recognizing Moroccan bee bread as being a valuable source of natural nutrients and considering it as a favorable product for human nutrition and health.

\section{Acknowledgements}

The authors are grateful to the Foundation for Science and Technology (FCT, Portugal) and FEDER under Programme PT2020 for financial support to CIMO (UID/AGR/00690/2013), A. Fernandes grant (SFRH/BPD/114753/2016), and L. Barros research contract. The authors are grateful to FEDER-Interreg España-Portugal programme for financial support through the project 0377_Iberphenol_6_E.

\section{References}

Abouda, Z., Zerdani, I., Kalalou, I., Faid, M., \& Ahami, M. T. (2011). The antibacterial activity of Moroccan bee bread and bee-pollen (fresh and dried) against pathogenic bacteria. Research Journal of Microbiology, 6, 376-384.

Akhir, R. A. M., Bakar, M. F. A., \& Sanusi, S. B. (2017). Antioxidant and antimicrobial activity of stingless bee bread and propolis extracts. AIP conference proceedings (pp. 1891). .

Andjelkovic, B., Jevtic, G., Markovic, J., Mladenovic, M., \& Pseva, V. (2012). Quality of honey bee bread collected in spring. Journal of Hygienic Engineering and Design, 1, 275-277.

AOAC (Association of Official Agricultural Chemists) (2016). In W. Horwitz, \& G. Latimer (Eds.). The official methods of analysis of AOAC international(20th ed.). Gaithersburg, MD, USA: AOAC International.

Bakour, M., Al-Waili, N. S., El Menyiy, N., Imtara, H., Figuira, A. C., Al-Waili, T., et al. (2017). Antioxidant activity and protective effect of bee bread (honey and pollen) in aluminum-induced anemia, elevation of inflammatory makers and hepato-renal toxicity. Journal of Food Science \& Technology, 54, 4205-4212.

Baltrušaitytè, V., Venskutonis, P. R., \& Čeksteryte, V. (2007). Radical scavenging activity of different floral origin honey and beebread phenolic extracts. Food Chemistry, 101, 502-514.

Barros, L., Pereira, E., Calhelha, R. C., Dueñas, M., Carvalho, A. M., Santos-Buelga, C., et al. (2013). Bioactivity and chemical characterization in hydrophilic and lipophilic compounds of Chenopodium ambrosioides L. Journal of Functional Foods, 5, 1732-1740.

Bessada, S. M. F., Barreira, J. C. M., Barros, L., Ferreira, I. C. F. R., \& Oliveira, M. B. P. P. (2016). Phenolic profile and antioxidant activity of Coleostephus myconis (L.) Rchb.f.: An underexploited and highly disseminated species. Industrial Crops and Products, 89, 45-51.

Brodschneider, R., \& Crailsheim, K. (2010). Nutrition and health in honey bees. Apidologie, 41, 278-294.

Brown, H. L., Roberts, A. E., Cooper, R., \& Jenkins, R. E. (2016). A review of selected bee products as potential anti-bacterial, anti-fungal, and anti-viral agents. Medical Research Archives, 4, 8.

Campos, M. G. R., Bogdanov, S., de Almeida-Muradian, L. B., Szczesna, T., Mancebo, Y., Frigerio, C., et al. (2008). Pollen composition and standardisation of analytical methods. Journal of Apicultural Research, 47, 154-161.

Čeksteryte, V., \& Jansen, E. (2012). Composition and content of fatty acids of various floral origin beebread collected in Lithuania and prepared for storage in different. Chemical Technology, 2, 57-61.

Čeksteryte, V., Navakauskiene, R., Treigyte, G., Jansen, E., Kurtinaitiene, B., Dabkevičiene, G., et al. (2016). Fatty acid profiles of monofloral clover beebread and pollen and proteomics of red clover (Trifolium pratense) pollen. Bioscience Biotechnology and Biochemistry, 80, 2100-2108.

Costa, M. C. A., Morgano, M. A., Ferreira, M. M. C., \& Milani, R. F. (2017). Analysis of bee pollen constituents from different Brazilian regions: Quantification by NIR spectroscopy and PLS regression. Lebensmittel-Wissenschaft und-Technologie-Food Science and Technology, 80, 76-83.

Fratini, F., Cilia, G., Mancini, S., \& Felicioli, A. (2016). Royal Jelly: An ancient remedy with remarkable antibacterial properties. Microbiological Research, 192, 130-141.

Hryniewicka, M., Karpinska, A., Kijewska, M., Turkowicz, M. J., \& Karpinska, J. (2016). LC/MS/MS analysis of $\alpha$-tocopherol and coenzyme Q 10 content in lyophilized royal jelly, beebread and drone homogenate: LC/MS/MS analysis of some bee products. Journal of Mass Spectrometry, 51, 1023-1029.

Human, H., \& Nicolson, S. W. (2006). Nutritional content of fresh, bee-collected and stored pollen of Aloe greatheadii var. davyana (Asphodelaceae). Phytochemistry, 67, 1486-1492.

Isidorov, V. A., Isidorova, A. G., Sczczepaniak, L., \& Czyżewska, U. (2009). Gas chromatographic-mass spectrometric investigation of the chemical composition of beebread. Food Chemistry, 115, 1056-1063.

Ivanišová, E., Kačániová, M., Frančáková, H., Petrová, J., Hutková, J., Brovarskyi, V., et al. (2015). Bee bread - perspective source of bioactive compounds for future. Potravinarstvo, 9, 592-598.

Kamonwannasit, S., Nantapong, N., Kumkrai, P., Luecha, P., Kupittayanant, S., \& Chudapongse, N. (2013). Antibacterial activity of Aquilaria crassna leaf extract against Staphylococcus epidermidis by disruption of cell wall. Annals of Clinical Microbiology and Antimicrobials, 12, 20.

Kaplan, M., Karaoglu, Ö., Eroglu, N., \& Silici, S. (2016). Fatty acid and proximate composition of bee bread. Food Technology and Biotechnology, 54, 497-504. 
Kieliszek, M., Piwowarek, K., Kot, A. M., Błażejak, S., Chlebowska-Śmigiel, A., \& Wolska, I. (2018). Pollen and bee bread as new health-oriented products: A review. Trends in Food Science \& Technology, 71, 170-180.

Kostić, A.Ž., Barać, M. B., Stanojević, S. P., Milojković-Opsenica, D. M., Tešić, Ž. L., Šikoparija, B., et al. (2015). Physicochemical composition and techno-functional properties of bee pollen collected in Serbia. Lebensmittel-Wissenschaft und -Technologie- Food Science and Technology, 62, 301-309.

Loper, G. M., Standifer, L. N., Thompson, M. J., \& Gilliam, M. (1980). Biochemistry and microbiology of bee-collected almond (Prunus dulcis) pollen and bee bread. Apidologie, 11, 63-73.

Markiewicz-Zukowska, R., Naliwajko, S. K., Bartosiuk, E., Moskwa, J., Isidorov, V., Soroczyńska, J., et al. (2013). Chemical composition and antioxidant activity of beebread, and its influence on the glioblastoma cell line (U87MG). Journal of Apicultural Science, 57, 147-157.

Miguel, M. da G., Doughmi, O., Aazza, S., Antunes, D., \& Lyoussi, B. (2014). Antioxidant, anti-inflammatory and acetylcholinesterase inhibitory activities of propolis from different regions of Morocco. Food Science and Biotechnology, 23, 313-322.

Oltica, S., Mărghitaş, L. Al, \& Dezmirean, D. (2007). Examination of antioxidant capacity of beebread extracts by different complementary assays. Bulletin of Ube College, 63,64 .

Padmanabhan, P., \& Jangle, S. N. (2012). Evaluation of DPPH radical scavenging activity and reducing power of four selected medicinal plants and their combinations. International Journal of Pharmaceutical Sciences and Drug Research, 4, 143-146.

Saavedra-Carhuatocto, D. M., Aguinaga-Castro, F., Rojas-Idrogo, C., \& Delgado-Paredes, G. E. (2014). Analysis of pollen loads collected by honey bees (Apis mellifera L.) from lambayeque province (Peru): Botanical origin and protein content. Journal of Global Biosciences, 3, 285-298 ISSN.

Schüler, L., \& Hemp, A. (2016). Atlas of pollen and spores and their parent taxa of Mt Kilimanjaro and tropical East Africa. Quaternary International, 425, 301-386.

Sobral, F., Calhelha, R., Barros, L., Dueñas, M., Tomás, A., Santos-Buelga, C., et al. (2017). Flavonoid composition and antitumor activity of bee bread collected in northeast Portugal. Molecules, 22, 248.

Sobral, F., Sampaio, A., Falcão, S., Queiroz, M. J. R. P., Calhelha, R. C., Vilas-Boas, M., et al. (2016). Chemical characterization, antioxidant, anti-inflammatory and cytotoxic properties of bee venom collected in Northeast Portugal. Food and Chemical Toxicology, 94, 172-177.

Soković, M., Glamočlija, J., Marin, P. D., Brkić, D., \& Griensven, L. J. L. D. van (2010). Antibacterial effects of the essential oils of commonly consumed medicinal herbs using an in vitro model. Molecules, 15, 7532-7546.

Stanciu, O. G., Marghitas, L. Al, \& Dezmirean, D. (2009). Macro-and oligo-mineral elements from honeybee-collected pollen and beebread harvested from Transylvania (Romania). Bulletin of University of Agricultural Sciences and Veterinary Medicine ClujNapoca - Animal Science and Biotechnologies, 66, 1-2.

Tavdidishvili, D., Khutsidze, T., Pkhakadze, M., Vanidze, M., \& Kalandia, A. (2014). Flavonoids in Georgian bee bread and bee pollen. Journal of Chemistry and Chemical Engineering, 8, 676-681.

Urcan, A., Criste, A., Dezmirean, D., Mărgăoan, R., Caeiro, A., \& Graça Campos, M. (2018). Similarity of data from bee bread with the same taxa collected in India and Romania. Molecules, 23, 2491.

Urcan, A., Mărghitas, L. A., Dezmirean, D. S., Bobis, O., Bonta, V., Mureșan, C. I., et al (2017). Chemical composition and biological activities of beebread-review. Bulletin of the university of agricultural sciences \& veterinary medicine Cluj-Napoca. Animal Science \& Biotechnologies, 74, 6-14.

Vattem, D. A., Lin, Y.-T., Labbe, R. G., \& Shetty, K. (2004). Antimicrobial activity against select food-borne pathogens by phenolic antioxidants enriched in cranberry pomace by solid-state bioprocessing using the food grade fungus Rhizopus oligosporus. Process Biochemistry, 39, 1939-1946.

Zengin, G., Arkan, T., Aktumsek, A., Guler, G. O., \& Cakmak, Y. S. (2013). A study on antioxidant capacities and fatty acid compositions of two daphne species from Turkey: New sources of antioxidants and essential fatty acids. Journal of Food Biochemistry, 37, 646-653.

Zhou, J., Qi, Y., Ritho, J., Zhang, Y., Zheng, X., Wu, L., et al. (2015). Flavonoid glycosides as floral origin markers to discriminate of unifloral bee pollen by LC-MS/MS. Food Control, 57, 54-61.

Zuluaga, C. M., Serratob, J. C., \& Quicazana, M. C. (2015). Chemical, nutritional and bioactive characterization of Colombian bee-bread. Chemical Engineering, 43, 175-180. 